\title{
Tourism Breeding Environment: Business Processes Applied to Collaborative Networks in Tourism and Entertainment Sector
}

\author{
Leandro Loss ${ }^{1}$ and Servane Crave ${ }^{2}$ \\ ${ }^{1}$ Axia Value Chain, \\ Av. Nações Unidas - 12551, CEP 04578-903, \\ São Paulo - SP, Brazil \\ leandro.loss@axiavaluechain.com \\ ${ }^{2}$ Orange Labs R\&D, \\ 905, rue Albert Einstein, 06921, \\ Sophia Antipolis Cedex, France \\ servane.crave@orange-ftgroup.com
}

\begin{abstract}
This paper introduces the concepts related to Distributed Business Processes (DBPs) associated to collaborative networks when applied to tourism and entertainment sector. These concepts are framed by the coordination activities and services orchestration to be used by tourism and entertainment providers. It brings to light the investigation about the needs associated to the tourism and entertainment areas when working collaboratively. There is a lack of ability for the service providers to recognize customers' wishes in order to address their loyalty. Tourism and entertainment services are characterized as temporary arrangements that are well served by the arrangements provided in collaborative networks. This paper presents the enablers and the uncertainties related to the area in order to provide alternative solutions to cover the emergent needs, facilitate the enablers, and mitigate the uncertainties identified so far.
\end{abstract}

Keywords: Tourism, Entertainment, Distributed Business Process, Tourism Breeding Environment, Virtual Tourism Organization.

\section{Introduction}

A business process can be understood as a representation of what an organization is going to do in a given business, regardless of its complexity, size and quantity. It can involve manufacturing processes, services, shipment, storage and many other activities [1]. Business processes are therefore seen as a collection of activities that are performed daily or hourly or by the minute within an organization. Some of these activities are performed automatically while some require a high degree of human interaction. It is believed that formalizing key processes through business processes can support competitiveness, innovation, and allow a fast reconfiguration in order to react to market's changes and fluctuations.

New ways of thinking the enterprises structures have been observed on the opposite of the centralized and isolated activities [2]. The organizational 
reconfiguration has been changing since Taylor and Ford's ideas, when organizations were hierarchical and bureaucratic. New approaches by which organizations work have evolved from an entirely competitive environment among the actors to a collaboration environment in order to act in response to customers' wishes.

It is therefore possible to argue that in many organizations a shift occurs from a supply chain perspective where "products definitions and customer needs of enterprises are stable and well defined" [3] to a value network where "it is considered any web of relationships that generates tangible and intangible values through complex dynamics between two or more individuals, groups or organizations" [4]. It requires an evolution in the way business processes are seen and performed. Business processes shall not only evolve from a centralized and internal perspective, but also consider the increase of activities being done by other partners. As a result, the concept of Distributed Business Process (DBPs) has risen. According to [1], a DBP is "a dynamic and temporary set of business processes which jointly gives rise to the end product or service".

This paper describes how DBPs can be associated to the concepts of collaborative networks and be used for coordination activities and services orchestration in the tourism and entertainment providers. The paper is structured as follows: section 2 brings to light the main requirements to the shift from a centralized business to a DBP perspective. Section 3 investigates the tourism and entertainment main needs. Section 4 presents the enablers and uncertainties related to the tourism and entertainment sector while section 5 introduces how the concepts of collaborative networks associated to DBPs can provide alternative solutions to cover emerging needs, facilitate the enablers and mitigate the uncertainties identified so far. Section 6 reports the results with potential customers and brings the final considerations of this work.

Table 1. Requirements to move from Business Processes to DBPs

\begin{tabular}{c|l}
\hline Requirements & \multicolumn{1}{c}{ Moving from Business Process to DBPs } \\
Communication & $\begin{array}{l}\text { When joining people from two or more organizations, it is possible that } \\
\text { they do not speak the same language. It may create barriers for the } \\
\text { business development. There are cases in which people speak the same } \\
\text { language, but there may occur problems of synonymy and polysemy. The } \\
\text { former refers to different words and phrases that express the same } \\
\text { concept, while the latter refers to words that can have multiple meanings. }\end{array}$ \\
\hline $\begin{array}{c}\text { Data } \\
\text { Interchange / }\end{array}$ & $\begin{array}{l}\text { There is a necessity of structured transmission of data between } \\
\text { organizations by electronic means. It requires the use of standards like } \\
\text { XML, ebXML, or WS-BPEL. }\end{array}$ \\
\hline $\begin{array}{c}\text { Real time } \\
\text { response }\end{array}$ & $\begin{array}{l}\text { It refers to issues related to time constraints. Partners need to provide } \\
\text { information about availability and resources in a strict deadline. }\end{array}$ \\
\hline $\begin{array}{c}\text { Cooperation and } \\
\text { collaboration }\end{array}$ & $\begin{array}{l}\text { Cooperation and collaboration involves not only information exchange } \\
\text { and adjustments of activities, but also sharing resources for achieving } \\
\text { compatible goals. }\end{array}$ \\
\hline Coordination & Aligning and altering activities so that results can be achieved efficiently. \\
\hline Traceability & $\begin{array}{l}\text { Modifications of requirements specifications affect other partners and } \\
\text { even the final customer. }\end{array}$ \\
\hline The Long Tail & $\begin{array}{l}\text { To provide strategies to sell a large number of unique items in relatively } \\
\text { small quantities. }\end{array}$ \\
\hline
\end{tabular}




\section{Approaching Distributed Business Process}

When moving from business processes to DBPs and collaborative approaches, organizations should take into account the value network perspective (Table 1). The business sector that benefits from the potential and the efficiency DBPs is the tourism and entertainment . Customers are getting more and more connected and looking for dynamic and easy composition offers as well as new experiences [5]. It has been observed that individual preferences are not fully taken into consideration by all actors in this sector in order to maximize customers' satisfaction.

\section{Tourism and Entertainment Needs}

According to the World Tourism Organization [5], tourism has become a popular global leisure activity. The tourism and entertainment service industries include a wide range of actors (Table 2).

Table 2. Classification of actors in tourism and entertainment sector

\begin{tabular}{c|l}
\hline Area & \multicolumn{1}{c}{ Actors } \\
\hline $\begin{array}{c}\text { Transportation } \\
\text { services }\end{array}$ & $\begin{array}{l}\text { Airline companies; Cruise ships; Trains; Buses; Taxis; Car rental agencies; } \\
\text { among others. }\end{array}$ \\
\hline $\begin{array}{c}\text { Hospitality } \\
\text { services }\end{array}$ & $\begin{array}{l}\text { Hotels; Hostels; Resorts; Guest houses; Camping; Bed \& breakfast; among } \\
\text { others. }\end{array}$ \\
\hline $\begin{array}{c}\text { Entertainment } \\
\text { venues }\end{array}$ & $\begin{array}{l}\text { Amusement parks; Casinos; Shopping malls; Music venues; Theatres; } \\
\text { Cinemas; Museums; Galleries; Operas; Night clubs; Restaurants; Kart } \\
\text { club; Golf club; among others. }\end{array}$ \\
\hline Others & $\begin{array}{l}\text { Tourism offices; Tourist guides; Weather forecast; Guides (on-line, paper- } \\
\text { based); Voyage agencies; among others. }\end{array}$ \\
\hline
\end{tabular}

These actors are usually working either isolated or in a low level of integration without taking advantage of the value network which they are part of. Service providers do not fully investigate the potential of this market and usually do not take into consideration the customers' personal wishes and previous experiences when proposing a new offer. The few situations whenever it happens, customers have to fill up their profiles in different websites. There is a lack of ability for service providers to recognize customers' wishes in order to address their fidelity.

Joint efforts shall provide new and innovative offers. Providing options to customers, and exploring the potential of a distributed approach add value to the network of service providers. Most of the service providers act in a reactive and not in a proactive fashion. It means that they wait for customers to contact them, and only then, trigger an action. They are still attracting customers through traditional market campaigns. Acting proactively implies in direct offers that fit to what customers are looking for or expecting. An alternative is to identify the customers' desires through the analysis of their profiles. Tourism and entertainment services are characterized as temporary arrangements (they do not last forever). These dynamic and temporal characteristics are well served by the arrangements provided in collaborative 
networks, such as Virtual Organization Breeding Environments and Virtual Organizations (see section 5).

The interaction with or among customers starts earlier and earlier in the purchasing phase. Years ago, buying a trip meant a physical meeting in a travel agency. Travel agents were tour planners, as well as sales agents, for travel suppliers. This situation no longer exists, and the tourism and entertainment sector has been changing dramatically. There is an opportunity to improve productivity by encouraging customers to use self-service. The structure is currently acquiring more decentralized market characteristics where each buyer/consumer has direct access to each seller/provider [6]. When a tourist "on his/her own" needs to find information from different providers, it is extremely difficult to know where to find the proper information. Besides that, customers are increasingly demanding personalized offers of travel products and services.

\section{Enablers and Uncertainties}

Trends affecting the tourism and entertainment industry generally include changing customer's demands, increased expectations in terms of value and convenience, and increasingly knowledgeable consumers who are themselves users of IT [6]. [7] argue that the widespread use of Internet and electronic market places together with increased competition and changing customer needs have fundamentally transformed the travel and entertainment service industry. Competitors have undermined their traditional business models. A large number of travel transactions and services have moved to the Internet.

By Observing this trend, [8] coined the term "cybermediaries". They have leaner cost structures, by reaching a global perspective and supplying technologically enabled economies of scale (large volumes at low transaction costs). Service providers in tourism and entertainment have to reposition their value propositions and provide greater value-added services based on the integration of Internet technologies and new marketing strategies.

There is the need not only for differentiated product strategies, but also for service level strategies. One example is the provision of highly personalized product and service packages involving high quality information and advisory services [7]. This trend is also supported by the idea of prosumption (production/consumption). [9] refer to the creation of products and services by the same people who will ultimately use them. The tourism and entertainment sector may use and get involve with end-users in order to adapt services to what customers are looking for. This kind of adaptation is then supported by good DBPs structures.

Interaction among customers is highly valuable as well. By putting a natural language question to a travel community the customer not only gets relevant answers for a vaguely formulated need, but also obtains additional relevant information, which he/she had not realized as part of his/her information need before this experience [7].

According to [3], "Web 2.0 encompasses a seemingly unlimited range of services, these services do have a number of common features": a) Internet is used as a low cost delivery platform; b) they involve the direct participation and tap into the creativity of a huge community of end users; c) they "emerge" rather than being " 
pre-defined". Moreover, there are no pointers to an integrated solution, based on Web 2.0 to join different services. On the other hand, Internet information is fragmented. It takes a significant amount of time to find good information, even for experienced travelers. The configuration of highly personalized products is extremely timeconsuming, and the trustworthiness of many sources can still not be verified [7].

Nowadays customers are also looking for a better use of available technologies, lower costs, transparent and real-time transactions. The challenge is to develop and provide customers with rich experiences before and during their tourism and entertainment activities, so that customers can actively participate during the entire process (do it yourself!). The ways of interacting with the customers may range from simple SMS messages, posts in blogs, social networks, e-mails and also the advent of the new phenomenum called micro-blogging, like Twitter.

It is important to provide new and innovative services for tourism and entertainment so that each customer can be seen as unique. It means that each service is one-of-a-kind and fits to each specific customer's requirement or profile. In order to offer this kind of unique service for the customers, it is necessary to combine and organize multiple actors in order to add value to the service being provided. Modeling DBPs among multiple actors shall speed up the answers to potential customers.

\section{Framing Tourism and Entertainment into Collaborative Networks}

One suggestion to support the shift from a traditional business process perspective that is intra-organizational (centralized and isolated) to a DBPs perspective that is inter-organizational (distributed and collaborative) is the concept of Tourism Breeding Environment. A Tourism Breeding Environment is defined here as a set of organizations, usually service providers that agree cooperating with each other while adopting common operating principles and infrastructures. The Tourism Breeding Environment's main goal is to provide high quality tourist and entertainment services in a seamless and transparent way to the customer ${ }^{1}$. The actors previously identified in Table 3 are the ones to potentially populate the Tourism Breeding Environment.

Service providers organized like a Tourism Breeding Environment may easily achieve the basic requirements necessary in order to establish their DBPs than the ones that are not working in a collaborative way. Tourism Breeding Environment provides common communication channels, up-to-date information, coordination mechanisms, as well as support for the definition of distributed business to ensure that the customer will be satisfied with a set of service providers.

On the other hand, in order to offer better and adapted services, customers shall keep their profiles and their preferences updated. Customers' profiles shall contain their general information, main interests, time and budget availability, and other additional information that may be relevant, allowing an interface with the customers and providing suggestions when planning a trip and/or last minute tips.

\footnotetext{
${ }^{1}$ The definition of Tourism Breeding Environment is an adaptation of the Virtual Organization Breeding Environment definition coined by [10].
} 
Not all service providers will interact with one single customer. Only a set of selected (either by the customer, or by an automatic composition of service, or any other criteria) service providers will work together. The selection of specific service providers opens space to the creation of a Virtual Organization that is being called Virtual Tourism Organization. The Virtual Tourism Organization emerges from the Tourism Breeding Environment as a temporary service provider. A Virtual Tourism Organization is seen as a temporary alliance among tourism and entertainment service providers that come together to deliver one-of-a-kind offer and value-added services. The Virtual Tourism Organization is set up during the customer's offer proposition and it is dismantled as soon as the service is provided. It is worth to highlight the importance of DBPs in this stage in order to harmonize interactions between service providers and their fast reaction to attend the customers' expectations. The Virtual Tourism Organization is then completely transparent to the customers. It means that the customer interface is always the same, but the service providers may change according to the customers' preferences.

The concept of Virtual Tourism Organization matches the dynamicity and reactivity that customers increasingly expect especially when using mobile and internet when they are traveling. Table 3 presents how a Virtual Tourism Organization fits the tourism and entertainment needs:

Table 3. Tourism and Entertainment Needs

\begin{tabular}{c|l}
\hline Tourism needs & \multicolumn{1}{c}{ Virtual Tourism Organization } \\
\hline Temporary & They are created in order to supply a, usually short, time-frame offer. \\
\hline $\begin{array}{c}\text { One-of-a-kind } \\
\text { services }\end{array}$ & $\begin{array}{l}\text { A Virtual Tourism Organization allows a dynamic organization of } \\
\text { service providers and resources that fits with customers' specific } \\
\text { requirements. Customers do not need to adapt themselves to pre-defined } \\
\text { tourism and entertainment packages. It is the Virtual Tourism } \\
\text { Organization that is adapted to the customer. }\end{array}$ \\
\hline $\begin{array}{c}\text { Push and Pull } \\
\text { information / } \\
\text { offers }\end{array}$ & $\begin{array}{l}\text { New services and suggestions can be offered to the customers. } \\
\text { Information or offer of services shall be provided to the customers either } \\
\text { according to their profiles or according to contextual data (weather, } \\
\text { traffic, location-based services, and so on). }\end{array}$ \\
\hline Real time & $\begin{array}{l}\text { Virtual Tourism Organizations can be built and reconfigured "on the fly" } \\
\text { in order to attend the customers' wishes (supported by DBPs). }\end{array}$ \\
\hline $\begin{array}{c}\text { Flexibility and } \\
\text { dynamic } \\
\text { arrangement }\end{array}$ & $\begin{array}{l}\text { A Virtual Tourism Organization can adapt itself in case of unforeseen } \\
\text { events by providing new offers to the customers. }\end{array}$ \\
\hline Co-creation & $\begin{array}{l}\text { Customers may provide suggestions to the tourism breeding environment } \\
\text { and influence in the arrangement of the Virtual Tourism Organization, as } \\
\text { well as evaluate the quality of the service being provided. }\end{array}$ \\
\hline Pricing & $\begin{array}{l}\text { Most of the customers look for lower prices and better services. The } \\
\text { Virtual Tourism Organization may provide a combination of services } \\
\text { that allows discounts and high quality services. }\end{array}$ \\
\hline
\end{tabular}

It is possible to cross-compare the tourism and entertainment needs to the requirements to move from a business process to a DBP perspective (Table 4). Many of the Tourism Breeding Environment needs can be supported by DBP and leveraged by their usage through a Virtual Tourism Organization environment. 
Table 4. Cross-comparison: DBPs requirements vs. Tourism and Entertainment Needs

\begin{tabular}{|c|c|c|c|c|c|c|c|}
\hline $\begin{array}{l}\text { T\&E } \\
\text { Needs } \\
\text { DBP } \\
\text { Requirements }\end{array}$ & $\begin{array}{l}\text { Tempo- } \\
\text { ray }\end{array}$ & $\begin{array}{l}\text { One- } \\
\text { of-a- } \\
\text { kind }\end{array}$ & $\begin{array}{l}\text { Push and } \\
\text { pull } \\
\text { informa- } \\
\text { tion / } \\
\text { offers }\end{array}$ & $\begin{array}{l}\text { Dyna- } \\
\text { micity }\end{array}$ & $\begin{array}{l}\text { Flexibi- } \\
\text { lity and } \\
\text { dynamic } \\
\text { arrange- } \\
\text { ments }\end{array}$ & $\begin{array}{l}\text { Co- } \\
\text { creation }\end{array}$ & Pricing \\
\hline Communication & $\sqrt{ }$ & $\sqrt{ }$ & $\sqrt{ }$ & $\sqrt{ }$ & $\sqrt{ }$ & $\sqrt{ }$ & $\sqrt{ }$ \\
\hline $\begin{array}{c}\text { Data } \\
\text { Interchange / } \\
\text { Interoperability }\end{array}$ & $\sqrt{ }$ & $\sqrt{ }$ & $\sqrt{ }$ & $\sqrt{ }$ & $\sqrt{ }$ & $\sqrt{ }$ & \\
\hline $\begin{array}{l}\text { Real-time } \\
\text { response }\end{array}$ & $\sqrt{ }$ & $\sqrt{ }$ & & $\sqrt{ }$ & $\sqrt{ }$ & & \\
\hline $\begin{array}{c}\text { Cooperation \& } \\
\text { collaboration }\end{array}$ & & $\sqrt{ }$ & $\sqrt{ }$ & $\sqrt{ }$ & $\sqrt{ }$ & & \\
\hline Coordination & & $\sqrt{ }$ & $\sqrt{ }$ & $\sqrt{ }$ & $\sqrt{ }$ & $\sqrt{ }$ & $\sqrt{ }$ \\
\hline Traceability & & $\sqrt{ }$ & & & $\sqrt{ }$ & $\sqrt{ }$ & \\
\hline Long Tail & & $\sqrt{ }$ & & $\sqrt{ }$ & $\sqrt{ }$ & $\sqrt{ }$ & \\
\hline
\end{tabular}

\section{General Considerations}

A preliminary study was elaborated in order to evaluate the concept behind the Tourism Breeding Environment and Virtual Tourism Organization concepts to support a value network for the tourism and entertainment sector. The main objective was to collect from potential end-users' their opinion. Users were requested to answer about the opportunity of receiving a pack of services related to tourism and entertainment. It was explained that services would be offered through the customer's mobile phone in a one-of-a-kind fashion. It was made clear that in order to avoid being intrusive or to disturb customers' daily life, the offers would be sent only if the customer had authorized them.

The questionnaire was made available on-line during two months. During this period invited people provided their opinions and their comments. A close look to the numbers showed that $46 \%$ of the replies were provided by men and $54 \%$ of the replies were provided by women. When considering the age of the responders, it was observed that people aged between 25 and 45 years old composed most of them $(68 \%)$. These people represent the customers that are able to spend more money in tourism and entertainment activities. It also shows that the questionnaire did not approach the so-called "Y generation" and a future study shall consider this target population. "Y generation" importance appears as the new consumers to come and their power in adapting themselves to new and innovative solutions must be kept in mind. The questionnaire also showed that most of the responders were married or living in couples. It provided a hint that couples tend to better program their tourism and entertainment activities in advance, while single people look for possible options "on-the-fly". It also demonstrated the responders' preference to choose/pick a pack of 
services composed by restaurants and cultural activities, like cinema, theater and so forth. It was observed that, when traveling, most of the people prefer staying in a hotel while traveling than staying in a friends' house or at their relatives'. Low-cost alternatives for accommodation complete the list. Most of them also book their accommodation by using a website, showing a tendency that privileges on-line services over the other traditional approaches (phone, physical).

Other important factors include quality, price, and originality of the service. As a result, Tourism Breeding Environment partners aligned by DBPs can mobilize their efforts to offer better services (quality) by integrating their activities, while a dynamic service composition can also bring original alternatives with special discounts and promotions. Despite the fact that most of the responders stated that they prepare their activities 2 days in advance or more, last-minute offers were welcome to overcome unpredictable events like delays and/or weather changes.

This work has provided a flavor about the potential of tourism breeding environment and virtual tourism organization concepts. It is important for the next steps to investigate the reaction of small-size service providers in tourism and entertainment to collect their opinions regarding collaborative work in a value network. Technical issues, like how to organize the payment of the pack of services, electronic identifiers, and a business model for the TBE are issues that shall not be underestimated and open new fields of research.

\section{References}

1. Pereira-Klen, A.P., Rabelo, R.J., Spinosa, L.M., Ferreira, A.C.: Distributed Business Process Management. In: PROVE 1999 Working Conf. on Infrastructures for VEs (1999)

2. Drucker, P.F.: Classic Drucker - The new society of organizations, pp. 127-138. Harvard Business School Press, Boston (2006)

3. Li, M., Crave, S., Grilo, A., van den Berg, R.: Unleashing the Potential of the European Knowledge Economy: Value Proposition for Enterprise Interoperability. European Commission: Info. Society and Media, Luxemburg (2008)

4. Allee, V.: A Value Network Approach for Modelling and Measuring Intangibles. In: Proceedings Transparent Enterprise, Madrid (November 2002)

5. World Tourism Organization (WTO 2009), Web page (2009), http: / / www . unwto. org/index.php (accessed in May 01, 2009)

6. Ammi, C.: International Scientific and Technical Encyclopedia. Global Consumer Behavior. International Scientific and Technical Encyclopedia (2007)

7. Novak, J., Schwabe, G.: Designing for reintermediation in the brick-and-mortar world: Towards the travel agency of the future. Electron Markets 19, 15-29 (2009)

8. Giaglis, G.M., Klein, S., O'Keefe, R.: Disintermetiation, reintermediation, or cybermetiation? The future of intermediaries in electronic marketplaces. In: Proceedings of the 12th Bled International Commerce Conference, Slovenia, Bled, June 7-9, pp. 389-407 (1999)

9. Tapscott, D., Williams, A.D.: Wikinomics: How Mass Collaboration Changes Everything, p. 320. Penguin, New York (2007)

10. Afsarmanesh, H., Camarinha-Matos, L.M.: A framework for management of virtual organizations breeding environments. In: Collaborative Networks and their Breeding Environments, pp. 35-48. Springer, Heidelberg (2005) 